\title{
PEMBERDAYAAN MASYARAKAT, KARANG TARUNA DAN DARMA WANITA DALAM MENGENTASKAN MASALAH SAMPAH DAN LIMBAH DI DESA PARUNG
}

\author{
Imas Kania Rahman ${ }^{1}$, Suherman, Zulfatun Niswah ${ }^{2}$ \\ imas.kania@uika-bogor.ac.id \\ Dosen Fakultas Agama Islam ${ }^{1}$, Mahasiswa KKN Kelompok 15 Tahun $2017^{2}$
}

\begin{abstract}
ABSTRAK
KKN Tematik Terintegrasi bagi masyarakat yakni untuk meningkatkan kesadaran masyarakat dengan berperan aktif dalam mengembangkan produktifitas sumber daya pembangunan sesuai dengan fasilitas yang dimiliki. Kegiatan KKN Tematik Terintegrasi UIKA Bogor Tahun 2017 merupakan salah satu kegiatan dengan pendekatan community development, dimana pada pelaksanaan kegiatan ini melakukan proses perencanaan sekaligus aksi program Pendampingan masyarakat baik pada aspek sosial, ekonomi, kesehatan, pendidikan, hukum, dan agama maupun teknologi tepat guna secara terpadu. KKN yang diselenggarakan tahun kelompok 15 Terpofokus di desa Parung, adalah sebuah desa yang sedang mengarah ke desa perkotaan dengan luas wilayah $\pm 168,259$ Hektar, terletak di kecamatan Parung, Kabupaten Bogor yang berbatasan langsung dengan Kota Depok. rendahnya tingkat pendidikan, sebagian besar warga Desa Parung bekerja sebagai pedagang di pasar. Kurangnya kepedulian warga RW 04 terhadap kebersihan lingkungannya, hampir seluruh warga RW 04 selalu membuang sampah ke jalanan, kebun, bantaran sungai, sehingga banyak sekali sampah-sampah organik maupun anorganik di sekitar lingkungan. Metode yang digunakan dalam pengabdian ini Pendekatan, Partisipasi Masyarakat dan Langkah Evaluasi.
\end{abstract}

Kata Kunci : KKN, Pemberdayaan Masyarakat, Sampah.

\section{PENDAHULUAN}

Kuliah Kerja Nyata adalah bagian dari sistem Pendidikan tinggi yang menempatkan Mahasiswa di luar Kampus agar mahasiswa hidup ditengah-tengah masyarakat bersama masyarakat untuk membantu dan mendampingi masyarakat memanfaatkan potensi sumberdaya alam lokal dan sumber daya manusia yang ada untuk mengatasi permasalahan masyarakat dalam kurun waktu tertentu. KKN Tematik Terintegrasi UIKA Bogor merupakan sebuah tuntutan/kewajiban bagi mahasiswa semester VII. Sasaran KKN Tematik
Terintegrasi bagi masyarakat yakni untuk meningkatkan kesadaran masyarakat dengan berperan aktif dalam mengembangkan produktifitas sumber daya pembangunan sesuai dengan fasilitas yang dimiliki. Lembaga Penelitian dan Pengabdian Masyarakat UIKA Bogor telah melaksanakan KKN Tematik Posdaya pada tahun 2007, KKN Terintegrasi pada tahun 2015 di Kabupaten Bogor, KKN Tematik Jawa Barat pada Tahun 2012 di Kota Depok, KKN Tematik Posdaya pada Tahun 2013 di Kabupaten Bogor, dan KKN Tematik Jabar pada Tahun 2013 di Kota Depok, KKN Tematik Jabar dan 
KKN Tematik Posdaya tahun 2014 dan 2015 Di Kecamatan Caringin, Cigombong, Dan Kecamatan Taman Sari Kabupaten Bogor.

Kegiatan KKN Tematik Terintegrasi UIKA Bogor Tahun 2017 merupakan salah satu kegiatan dengan pendekatan community development, dimana pada pelaksanaan kegiatan ini melakukan proses perencanaan sekaligus aksi program Pendampingan masyarakat baik pada aspek sosial, ekonomi, kesehatan, pendidikan, hukum, dan agama maupun teknologi tepat guna secara terpadu.

\section{Gambaran Umum Wilayah}

Desa Parung adalah sebuah desa yang sedang mengarah ke desa perkotaan dengan luas wilayah $\pm 168,259$ Hektar, terletak di kecamatan Parung, Kabupaten Bogor yang berbatasan langsung dengan Kota Depok yang secara geografis luas dan batas wilayah Desa Parung sebagai berikut:

\begin{tabular}{|c|l|c|}
\hline No & Keterangan & Berbatasan \\
\hline 1 & Utara & Desa Iwul \\
\hline 2 & Selatan & Desa Waru \\
\hline 3 & Barat & Desa Jabon \\
\hline 4 & Timur & Desa Pamegarsari \\
\hline
\end{tabular}

Karena dekat dengan pusat kota bogor memang daerah Waru ini susananya sudah modern atau dibilang desa semi Kota, dilihat dari cara berdaptasinya. Walaupun desa Waru berada dikabupaten Bogor namun dilihat dari bahasa, interaksi lebih kepada suku betawi.

\section{Jumlah Penduduk}

\begin{tabular}{|c|l|c|}
\hline No & Jenis Kelamin & Jumlah \\
\hline 1 & Laki-Laki & 7.999 \\
\hline 2 & Perempuan & 7.427 \\
\hline 3 & Kepala Keluarga & 5.482 \\
\hline
\end{tabular}

Dari data profil kelurahan diatas diperoleh tingkat kepadatan penduduk rata - rata untuk Desa 417 jiwa/km2.

\section{Pendidikan}

Berdasarkan laporan tahunan Kepala Desa Parung tahun 2017 dan dari hasil Observasi yang dilakukan dari tanggal 21 Juli - 2 Agustus 2017, berikut adalah tingkat pendidikan warga.

\begin{tabular}{|c|l|c|}
\hline No & Tingkat Pendidikan & Jumlah \\
\hline 1 & SD & 3.178 \\
\hline 2 & SMP & 1.128 \\
\hline 3 & SMA & 1.145 \\
\hline 4 & Akademik (D1-D3) & 161 \\
\hline 5 & Sarjana (S1-S3) & 101 \\
\hline 6 & Pondok Pesantren & 120 \\
\hline 7 & Madrasah & 80 \\
\hline 8 & Sedang Sekolah & 30 \\
\hline \multicolumn{2}{|c|}{ Pendidikan tampaknya dapat }
\end{tabular}
mempengaruhi beberapa aspek kehidupan masyarakat di Desa Parung, misalnya dalam kehidupan pendidikan dan keagamaan, ekonomi, kesehatan, sosial dan lingkungan. Pendidikan dimaksud berkait dengan pengetahuan, wawasan, serta kesadaran mayarakat. Dengan kata lain, rendahnya tingkat pendidikan tampaknya berpengaruh terhadap ekonomi dan kesehatan. Sebagai contoh, karena rendahnya tingkat pendidikan, sebagian besar warga Desa Parung bekerja sebagai pedagang di pasar. Kurangnya kepedulian warga RW 04 terhadap kebersihan lingkungannya, hampir seluruh warga RW 04 selalu membuang sampah ke jalanan, kebun, bantaran sungai, sehingga banyak sekali sampah-sampah organik maupun anorganik di sekitar lingkungan. 


\section{METODE PENGABDIAN}

Tahapan pelaksanaan untuk kegiatan ini sebagaimana terlihat pada bagan :

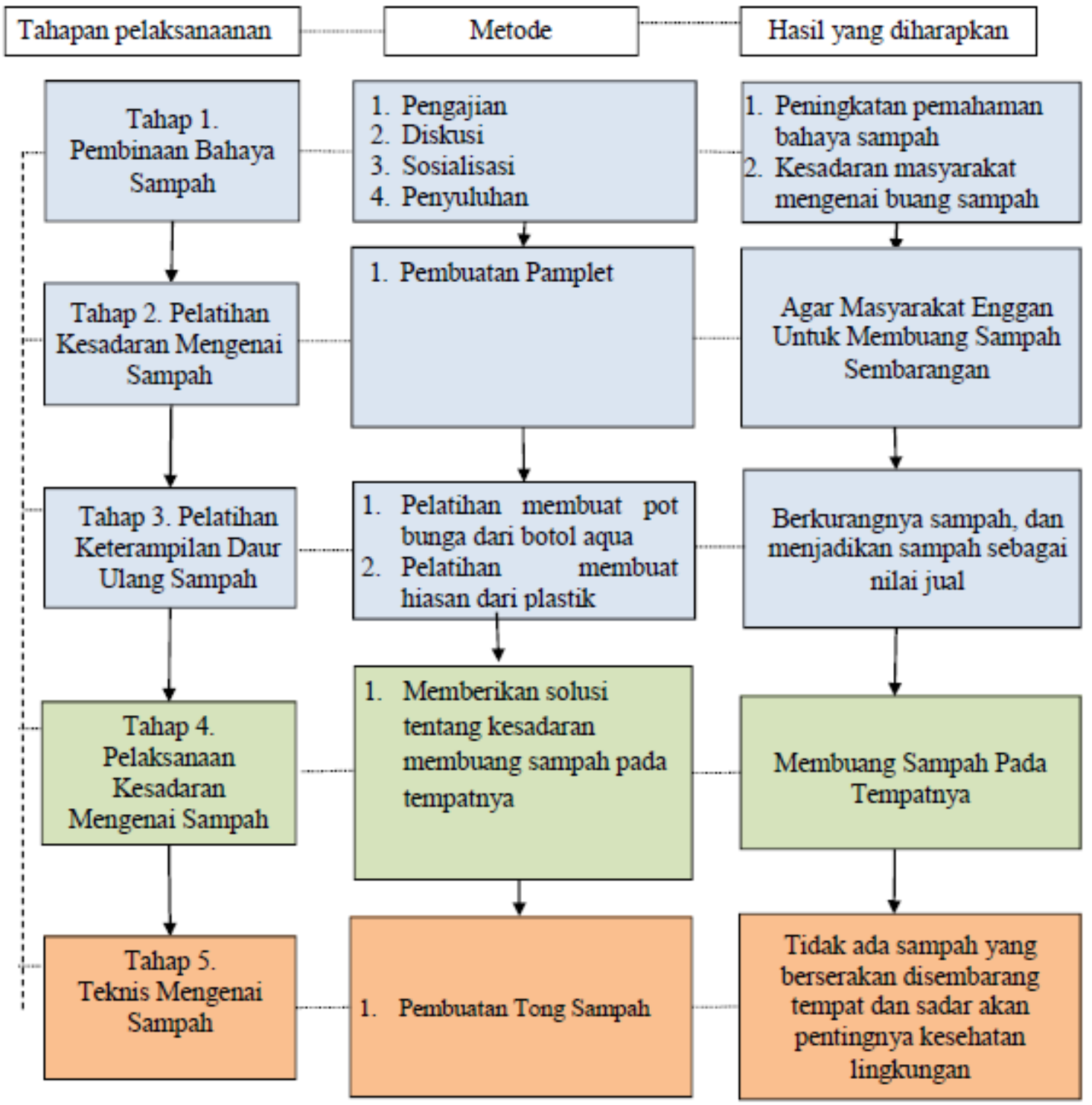


Jadwal Kegiatan

\begin{tabular}{|c|l|c|c|c|c|}
\hline \multirow{2}{*}{ No. Kegiatan } & \multicolumn{1}{|c|}{ Minggu } \\
\cline { 5 - 7 } & & \multicolumn{3}{|c|}{} \\
\cline { 5 - 7 } & & \multicolumn{1}{|c|}{ Penyusunan rencana kegiatan } & $\mathbf{2}$ & $\mathbf{3}$ & $\mathbf{4}$ \\
\hline 2 & Sosialisasi rencana kegiatan & & & \\
\hline 3 & Pengajian/pembinaan bahaya sampah & & & & \\
\hline 4 & Penyuluhan kebersihan lingkungan & & & & \\
\hline 5 & Sosialisasi & & & & \\
\hline 6 & Pembuatan pamplet & & & & \\
\hline 7 & Pelatihan pembuatan pot bunga aqua & & & \\
\hline 8 & Pelatihan pembuatan hiasan plastik & & & & \\
\hline 9 & $\begin{array}{l}\text { Pelaksaan solusi tentang kesadaran } \\
\text { masyarakat membuang sampah }\end{array}$ & & & & \\
\hline 10 & Pembuatan tong sampah & & & & \\
\hline 11 & Pembagian tong sampah & & & & \\
\hline 13 & Monitoring dan evaluasi & & & \\
\hline 14 & Penyusunan laporan & & & \\
\hline
\end{tabular}

\section{Metode Pendekatan}

Pendekatan yang digunakan dalam kegiatan ini adalah:

1. Pendekatan religius, yaitu pendekatan yang menggunakan nilai-nilai agama sebagai basis kegiatan. Pendekatan ini sangat penting karena permasalahan pemahaman bahaya sampah dalam masyarakat sangat dipengaruhi oleh faktor keimanan, pengalaman keagamaan, rasa tanggung jawab dan pengetahuan.

2. Pendekatan organisasi, yaitu pendekatan dimana seluruh kegiatan diorganisir oleh Paud Ar Rayyan dan Pemuda RISMA dan RISBA. Hal ini sesuai dengan hasil penelitian Bahari (2010) dimana dia menemukan bahwa keterlibatan organisasi mempunyai pengaruh langsung terhadap toleransi.

3. Pendekatan kekerabatan, artinya bahwa pembinaan yang dilakukan senantiasa dikaitkan dalam rangka membangun kekerabatan antar masyarakat yang semakin memudar. Nurhayati (2005) menemukan bahwa faktor pendukung toleransi umat Islam dengan Hindu adalah adanya sistem kekerabatan.

4. Pendekatan berdasarkan karakter masyarakat, yakni pembinaan yang dilakukan akan disesuaikan dengan karakter masyarakat. Joyce dan Weil (1996) mengungkapkan bahwa model pendidikan yang relevan dengan perilaku sosial dan nilai adalah dengan banyak memberikan permainan peran. Hal ini dilakukan untuk memberi pengalaman riil kepada peserta didik tentang sesuatu yang dilakukan atau dirasakan oleh orang lain. Memang, dalam prakteknya, tidak seluruh aspek harus menggunakan permainan ini. Dalam beberapa hal, terdapat kegiatankegiatan yang hanya golongan tertentu 
untuk melakukannya. Sejalan dengan konsep Joyce dan Weil, cooperative learning yang digagas Slavin (2005) dapat digunakan untuk membangun kesadaran toleransi masyarakat. Hal ini karena penekanan dari konsep pendidikan ini adalah kerjasama yang merupakan urat nadi toleransi. Dengan demikian, model pendidikan yang akan dibangun menggunakan dua konsep utama yaitu role playing model dan cooperative learning model.

\section{Partisipasi Masyarakat dalam Pelaksanaan Program}

Partisipasi masyarakat yang dapat dilakukan dalam kegiatan ini adalah sebagai berikut:

1. Mempersiapkan masyarakat yang bersedia mengikuti pembinaan baik tentang bahaya sampah maupun tentang kebersihan lingkungan.

2. Mempersiapkan tempat untuk pembinaan dan pelatihan.

3. Mempersiapkan tempat untuk pelatihan daur ulang sampah menjadi nilai jual.

4. Pelaksana kegiatan pembinaan, terutama tentang sampah.

5. Bersama-sama dengan Tim Pengusul melakukan monitoring pelaksanaan pembinaan dan pelatihan.

\section{Langkah Evaluasi}

Evaluasi yang akan dilakukan terdiri dari:

1. Evaluasi proses, yang terkait dengan perencanaan, pelaksanaan dan monitoring kegiatan. Evaluasi proses akan dilakukan setiap pekan bersama dengan masyarakat.

2. Evaluasi hasil, yang akan dilaksanakan setelah kegiatan dilaksanakan. Evaluasi hasil ditujukan untuk menguji pemahaman masyarakat tentang sampah dengan target capaian $100 \%$ tidak radikal. Selain itu, evaluasi hasil akan ditujukan pada peningkatan pendapatan masyarakat dengan target $80 \%$ masyarakat meningkat pendapatannya.

3. Evaluasi dampak, yang akan dilakukan 6 (enam) bulan setelah pelaksanaan pembinaan. Evaluasi dampak diarahkan untuk melihat efektivitas model pembinaan dan keberlangsungan industri rumah tangga (Gall, Gall, dan Borg, 2003).

\section{REALISASI PROGRAM}

Pelaksanaan KKN UIKA 2017 dimulai pada tanggal 7 Agustus 2017 sampai dengan 7 September 2017 yang pelaksanaannya dilakukan oleh KKN 15 dan masyarakat Kampung Jati . Adapun program KKN dirinci sebagai berikut:

\section{Program Bidang Pendidikan}

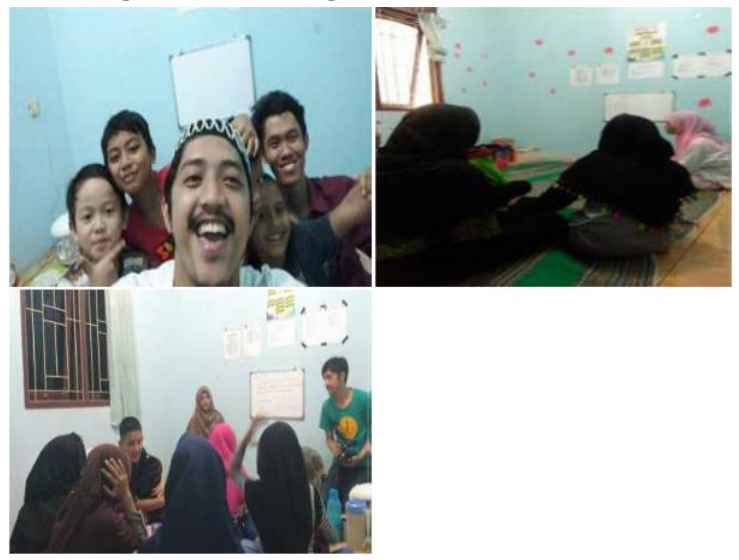

a. Bimbingan belajar bahasa inggris, bahasa arab dan matematika 


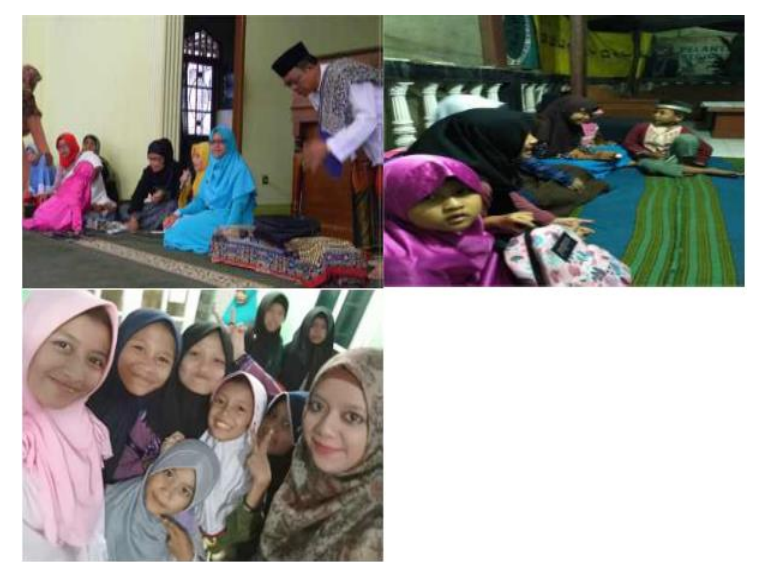

b. Mengajar BTQ (Baca Tulis Quran)

c. Pembuatan proposal untuk remaja

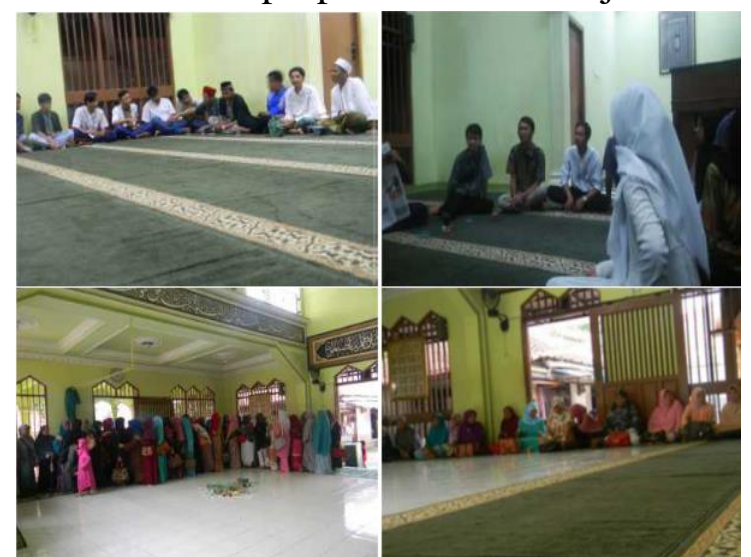

d. Kegiatan majlis ta'lim ibu-ibu dan bapak-bapak

e. Kegiatan darma wanita dan PKK

\section{Program Bidang Sosial}

a. Menyediakan tempat sampah untuk sampah organic dan sampah.

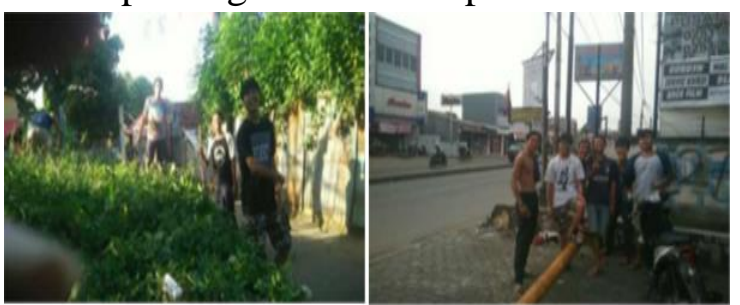

b. Kerja bakti mingguan.

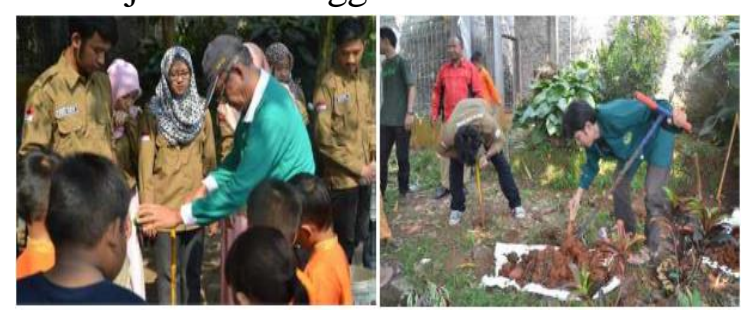

c. Pembuatan pupuk kompos.

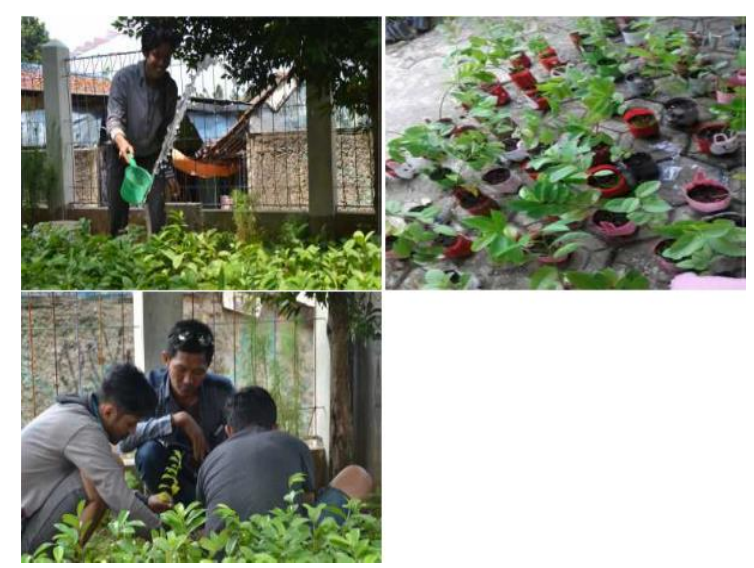

d. Pembuatan pot bunga dan penghijauan (Go Green).

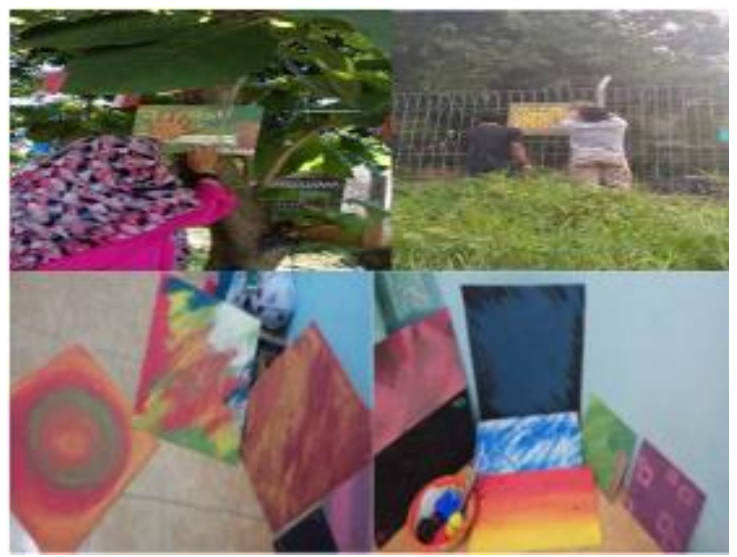

e. Pembuatan pamphlet tentang kebersihan.

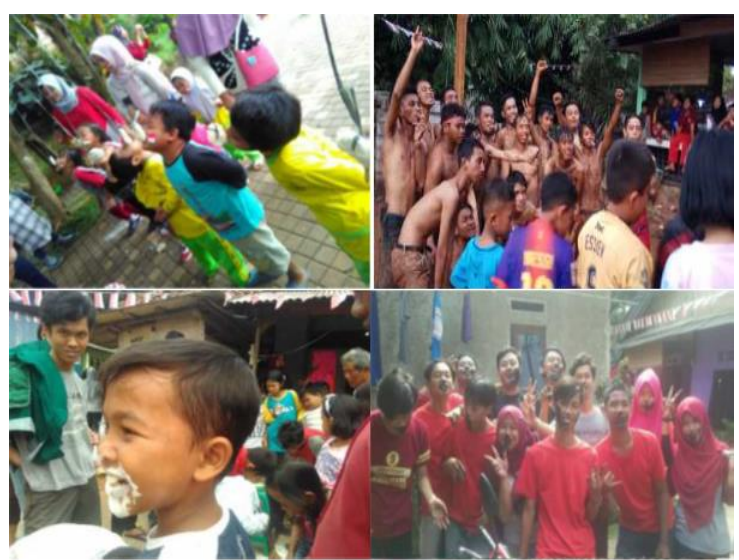

f. Mengadakan lomba 17 Agustus. 
3. Program Bidang Ekonomi

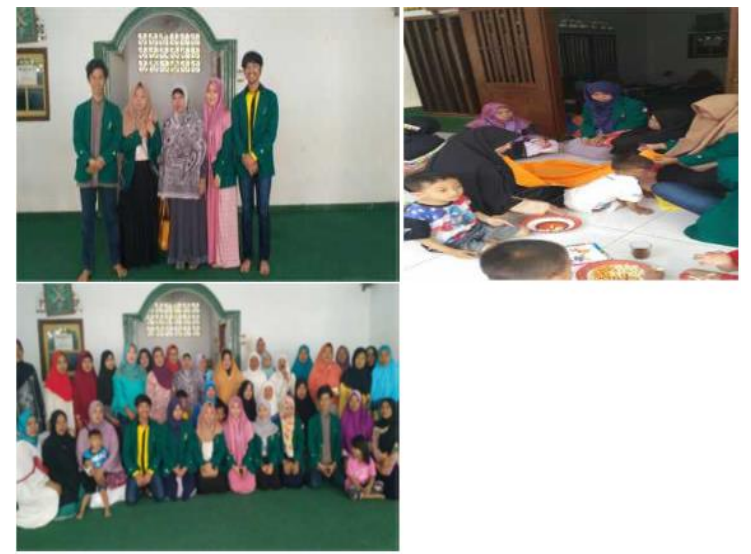

a. Penyuluhan Motivasi Kewirausahaan

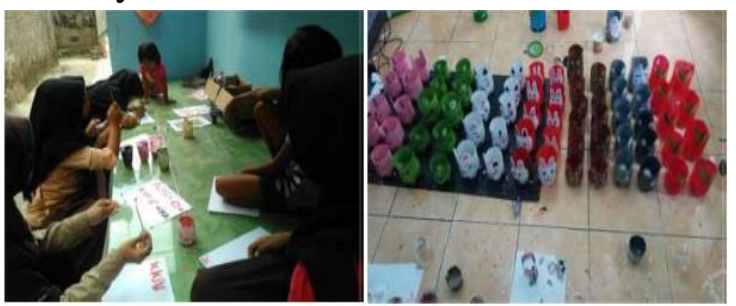

b. Kreativitas pemanfaatan sampah yang menghasilkan nilai jual

b. Pembentukan kelompok USMAN (Usaha mandiri) dalam pemanfaatan sampah rumah tangga dan usaha.

\section{Program Bidang Kesehatan}

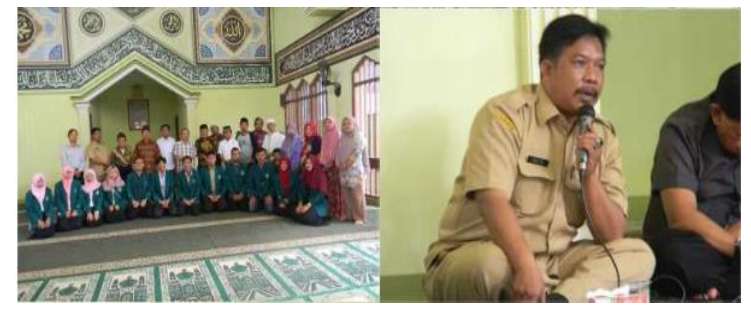

a. Penyuluhan kebersihan lingkungan

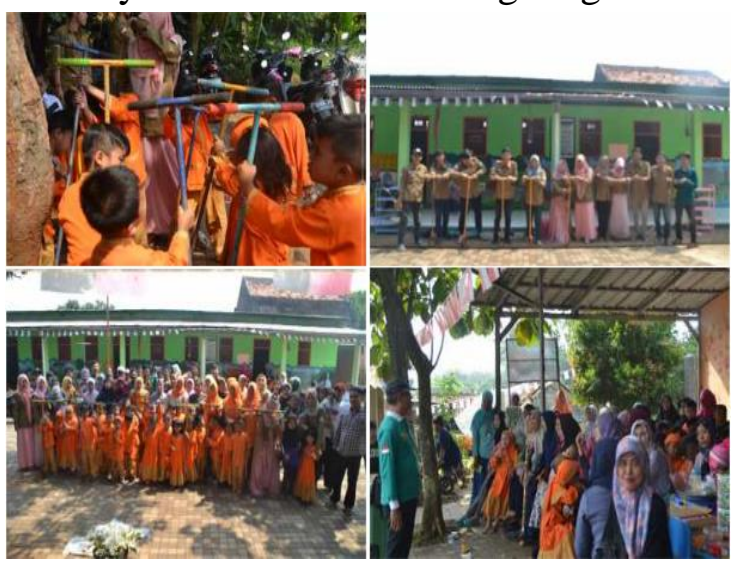

b. Memberantas limbah sampah

c. Mengenal potensi sampah d. Pergerakan pemuda atau masyarakat peduli sampah

e. Kesadaran dalam menjaga dan mempertahankan lingkungan sekitar rumah dalam mengurai sampah

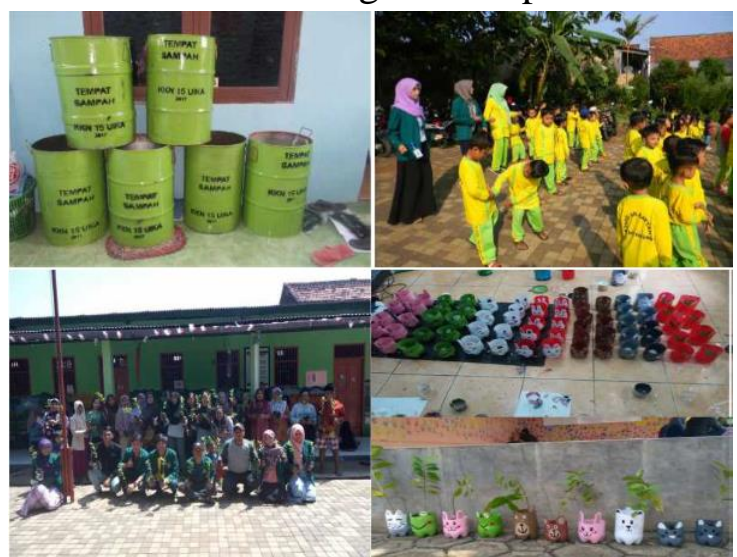

f. Sosialisasi tentang bahaya sampah dan cara pengelolaannya

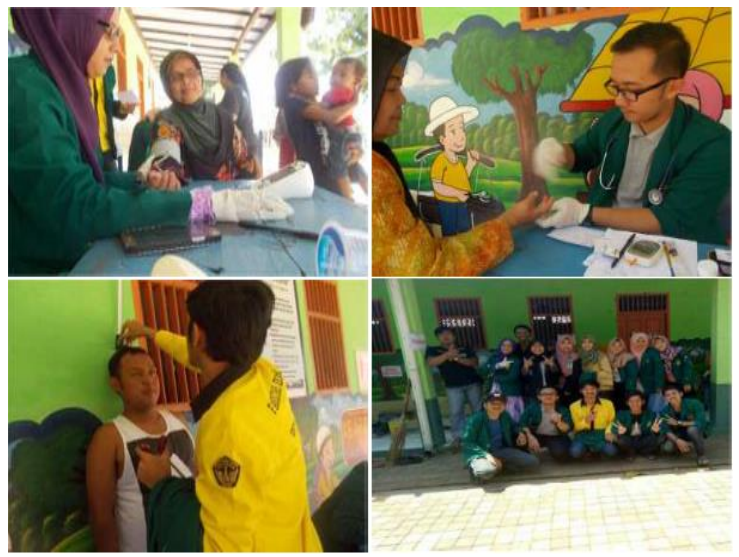

g. Mengadakan cek kesehatan gratis

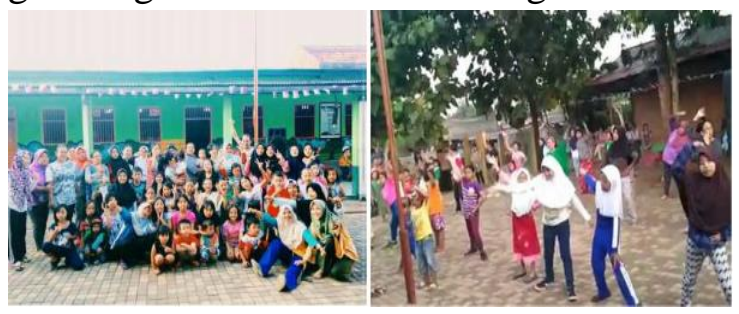

h. Senam sehat untuk lansia

\section{KESIMPULAN}

Kegiatan KKN dengan sasaran masyarakat Kampung Jati Desa Parung, Kecamatan Parung, Kabupaten Bogor sebagai bagian dari masyarakat secara umum berjalan dengan lancar sesuai dengan apa yang direncanakan dalam 
matrik program kerja KKN. Meski target waktu yang direncanakan dalam matrik rencana kerja tidak dapat sepenuhnya dijalankan sesuai dengan hal tersebut tidak merubah esensi pelaksanaan program tersebut.

Adapun kesimpulan dari pelaksanaan program kerja KKN masyarakat yaitu:

1. Program KKN dapat terlaksana dengan baik dan lancar meski ada beberapa perubahan dan tambahan serta waktu pelaksanaan yang kurang sesuai dengan yang direncanakan.

2. Program ini dapat berjalan dengan baik berkat dukungan dan kerjasama antar warga dan pihak masyarakat yang sangat membantu dan mendukung.

Dengan demikian, hasil kesimpulan di atas menunjukkan bahwa secara garis besar program KKN dapat dikatakan sukses dan lancar meskipun waktunya lebih maju atau lebih mundur.

\section{REFERENSI}

(2017) Pedoman Pelaporan PPM Uiversitas Ibn Khaldun Bogor, Bogor : LPPM UIKA

Tim Peneliti. (2006). Laporan Hasil Survei Pengetahuan, Sikap dan Perilaku Stakeholders terhadap Organisasi Masyarakat Sipil. Jakarta: LP3ES dan YAPPIKA.

Gall, M.D., Gall, J.P. dan Borg,W.R. (2003). Educational Research an Introduction. Boston: Pearson Education, Inc.

Joyce, Bruce dan Weil, Marsha. (1996). Models of Teaching. Boston: Allyn and Bacon.
Kusumadewi,L.R. (1999). Sikap dan Toleransi Beragama di Kalangan Mahasiswa: Studi di Tiga Perguruan Tinggi di Jakarta. Skripsi. Depok: FISIP UI.

Rachmawati, AFD. (2006). Toleransi Antar Umat Islam dan Katolik: Studi Kasus di Dukuh Kasaran, Desa Pasungan, Kecamatan Ceper, Kabupaten Klaten. Skripsi. Semarang: IAIN Walisongo.

Slavin, R.E. (2005). Cooperative learning: theory, research and practice. London: Allyn and Bacon.

Talib,A.T dan Gill, S.S. (2012). Socioreligious tolerance: exploring the Malaysian experience. Global Journal of Human Social Science. 12(8). 49-54.

Tim Penyusun. (2008). Toleransi dalam Pasungan: Pandangan Generasi Muda terhadap Masalah Kebangsaan, Pluralitas dan Kepemimpinan Nasional. Jakarta:SETARA Institute.A 